Muriel Rukeyser, America, and the "Melville Revival" Author(s): CATHERINE GANDER

Source: Journal of American Studies, Vol. 44, No. 4 (November 2010), pp. 759-775

Published by: Cambridge University Press on behalf of the British Association for

American Studies

Stable URL: https://www.jstor.org/stable/25790528

Accessed: 19-08-2019 10:36 UTC

\title{
REFERENCES
}

Linked references are available on JSTOR for this article:

https://www.jstor.org/stable/25790528?seq=1\&cid=pdf-reference\#references_tab_contents You may need to $\log$ in to JSTOR to access the linked references.

JSTOR is a not-for-profit service that helps scholars, researchers, and students discover, use, and build upon a wide range of content in a trusted digital archive. We use information technology and tools to increase productivity and facilitate new forms of scholarship. For more information about JSTOR, please contact support@jstor.org.

Your use of the JSTOR archive indicates your acceptance of the Terms \& Conditions of Use, available at https://about.jstor.org/terms

Cambridge University Press, British Association for American Studies are collaborating with JSTOR to digitize, preserve and extend access to Journal of American Studies 


\title{
Muriel Rukeyser, America, and the "Melville Revival"
}

\section{CATHERINE GANDER}

\begin{abstract}
Whilst Muriel Rukeyser's poetic affinity with Walt Whitman is generally acknowledged, the close relation of her work and poetic sensibility to the thought and writing of Herman Melville has somehow gone relatively unnoticed, and almost wholly unexamined. In I918, Van Wyck Brooks called for the creation of a usable past that would energize America by recasting its cultural tradition. His plea addressed the need to rebuild a national heritage via the rediscovery of culturally "great" figures. By the late 1930 , many scholars and writers had answered the call, and the new discipline of American studies was beginning to take shape, aided by a reclamation of one of the country's greatest, most neglected, writers - Herman Melville. This was also the period in which Rukeyser "came of age"; a time when political and international conflicts and economic crises generated both the stark, documentary representation of present social realities and the drive to retrieve or reconstruct a more golden age that might mobilize a dislocated nation. The following article examines the importance of Melville to Rukeyser's work, and situates her within the "Melville revival" as an important figure in the movement throughout the first half of the twentieth century to reconstruct an American cultural character.
\end{abstract}

In I9I s, Van Wyck Brooks's book America's Coming-of-Age was published, an extended critical essay issuing both an indictment of American life, and a cultural call to arms. Brooks's perception of America was of a literary and historical landscape "unchecked, uncharted, unorganized"; "a vast Sargasso Sea" in which "all manner of living things [were] ... rising and falling, floating and merging" without order or form. ${ }^{1}$ In I91 8, Brooks developed his critique in the Dial essay "On Creating a Usable Past," in which he contended that America was disabled by its inability to conjoin practical and creative life. The reason that the country had "no cultural economy, no abiding sense of spiritual values," was that the remembered American past was "a past without living value." Yet "if we need another past so badly," Brooks argued, "is it inconceivable that we might discover one, that we

Department of American Studies, University of East Anglia. Email: c.gander@uea.ac.uk.

${ }^{1}$ Van Wyck Brooks, America's Coming of Age (New York: E. P. Dutton and Co., 1915), reprinted in Claire Sprague, ed., Van Wyck Brooks, The Early Years (Boston: Northeastern University Press, 1968, rpr. 1993), 79-1 58, 149-50. 
might even invent one? "2 According to Brooks, the way to fill the "void" of the present was to retrieve history by a process of creation and selection. He therefore encouraged writers to choose their national tradition, directing his readers towards historical reinterpretation in order to construct a particularly American cultural identity. Creation of a "usable past," he contended, might well begin with the study of Herman Melville, who had been "so neglected" by Americans that there was to date "no biography of him."”

Three years later, Raymond Weaver published Herman Melville: Mariner and Mystic, thereby inaugurating what is known as the "Melville revival," a movement of cultural reclamation that lasted over three decades. ${ }^{4}$ The reason for Melville's revival was arguably due to a confluence of cultural and social needs and anxieties. Melville's sea-tales, laced with autobiography and the observations of the participant author, provided a personalized narrative of adventure that imposed form upon experience. Spanning two world wars and the Great Depression, the "Melville Revival" took shape during an extended period of cultural and economic national crisis. Many of Melville's works represented a fusion of fiction and fact, and as such, spoke to those Americans who were, as Gene Wise observed, driven by the need "to explain things, to make one's own experience, and the world around that experience, comprehensible." Additionally, in an era which saw the advent and development of documentary in the United States - a genre which arguably dominated the literary output of the country for over a decade - Melville's

2 Van Wyck Brooks, “On Creating a Usable Past," Dial LXIV (I I April I91 8), reprinted in Sprague, 219-26, 223.

3 Ibid., 224.

4 Several sources agree on this point, for example, Clare Spark, Hunting Captain Ahab: Psychological Warfare and the Melville Revival (Kent, $\mathrm{OH}$ and London: The Kent State University Press, 2001); and Sprague's Van Wyck Brooks. Essays and books partaking in the revival included D. H. Lawrence's Studies in Classic American Literature (London and Toronto: William Heineman Ltd, 1922); Lewis Mumford's The Golden Day (New York: Boni and Liveright, 1926) and Herman Melville (New York: Harcourt, Brace and Co., 1929); William Thorp's anthology Representative Selections of Herman Melville (New York: The American Book Company, 1929), and Weaver's volumes of Melville's collected works and journals; F. O. Matthiessen's American Renaissance (New York: Oxford University Press, 194I); William Ellery Sedgewick's Herman Melville: The Tragedy of Mind (New York: Oxford University Press, 1944); Charles Olson's Call Me Ishmael (San Francisco: City Lights Books, 1947); Richard Chase's Herman Melville: A Critical Study (New York: Macmillan, 1949); Newton Arvin's Herman Melville (New York: Sloane, 1950); Jay Leyda's The Melville Log: $A$ Documentary Life of Herman Melville, I819-189I (New York: Harcourt, Brace and Co., I95 I); and C. L. R. James's Mariners, Renegades and Castaways: The Story of Herman Melville and the World We Live In (New York: C. L. R. James, 1953).

5 Gene Wise, "'Paradigm Dramas' in American Studies: A Cultural and Institutional History of the Movement" (first published in American Quarterly, 3 I, 3, 1979), reprinted in Lucy Maddox, ed., Locating American Studies: The Evolution of a Discipline (Baltimore and London: The Johns Hopkins University Press, 1999), 166-210, 176, original emphasis. 
novels were an example of what might be called proto-documentary. The combined creative story and encyclopaedic explanation of shipping and whaling experience in Moby-Dick, for example, found a modern correlative in several documentary travel narratives, and adhered closely to John Grierson's definition of documentary as he coined the term in 1926 to mean "the creative treatment of actuality."

The revival of literary and cultural figures such as Whitman and Melville as representatives of a usable past during the first half of the twentieth century largely corresponded to the two writers' methods of recording American experience. The confluence of stark, factual documentation and psychological narrative in Melville, and the accumulative, poetic catalogues of visual experience in Whitman, helped render the authors subjects of an American past to be both studied and emulated, and their proto-documentary techniques encouraged and influenced writers in the 1930s, working both within and outside the academy. "For the first time," wrote Waldo Frank at the close of the 1920s, "the aesthetic and the national ... are joined dynamically in American literary action."

\section{MURIEL RUKEYSER AND HERMAN MELVILLE}

As Jane Cooper has noted, Rukeyser "came of age during the thirties ... a period of the most intense interest in all things American."8 While Cooper is right to highlight the contextual and intertextual nature of Rukeyser's work, she neglects to note how closely Rukeyser's interests either followed or prefigured shifting concerns within the burgeoning American studies movement, in particular the "Melville revival." Indeed, she writes that whilst historians and scholars "were engaged in radical reassessments of the American legacy and of the giants of our nineteenth-century literature," Rukeyser was "engaged in recovering her own usable past."

However, Rukeyser associated professionally and personally with several figures of the movement. Despite the clear relation of her poetic sensibility to the cultural criticism of Brooks, Waldo Frank and Lewis Mumford, the subject has received very little critical attention. Additionally, whilst several critics have placed Rukeyser in the Whitmanian tradition of the inclusive, democratic American poet, no sustained critical attention has been given to Rukeyser's affiliation with Melville, the importance of whose contribution

6 Forsyth Hardy, ed., Grierson on Documentary (London: Collins, I946), I I

7 Waldo Frank, The Rediscovery of America (New York, 1929), 318.

8 Jane Cooper, "Foreword: Meeting-Places," in Muriel Rukeyser, The Life of Poetry (Ashfield, MA: Paris Press, 1996; first published 1949), xviii.

9 Ibid., xix. Italics mine. 
to American letters Rukeyser considered equal to that of Whitman, asserting that "one cannot be repeated more than the other."10 It is clear from Rukeyser's published and unpublished work that she considered Melville's prose and poetry to be highly significant, both to the reconstruction of an American cultural tradition and to her own artistic principles. ${ }^{11}$

\section{“THE USABLE TRUTH”}

In 1941, Rukeyser wrote an article for Poetry magazine entitled 'The Usable 'Truth,' in which she bemoaned the American attitude to poetry in "education" as something "to be memorized and stored ... [but] not to be used." 12 In learning environments, strong emphasis was being placed on the use-value to modern life of written documents and historical artefacts. ${ }^{13}$ Rukeyser noted that although a usable "tradition" was being taught to a new generation, poetry was still widely considered a purely aesthetic art with no practical value: "In a utilitarian culture, this one knowledge is to be taught as being Not for Use."14

Having admitted to the influence of Frank upon her writing two years before, Rukeyser appears to allude to his understanding of American heritage as part of an organic "whole." Stressing that "whole ages are given to us" by the "grace" of "poetry alone," Rukeyser constructs an extended metaphor wherein the lessons of past ages are written both on the leaves of poetry books and on the fallen, compacted leaves of trees, which help to comprise the ground beneath the present generation's feet. She argues that the "earth of our learning" is not the "dust ground out of rock," but rather the "packed and leafdrift earth of centuries of falling lives, fallen under our feet,

10 The Life of Poetry, $8_{3}$; for Rukeyser and Whitman critiques see James E. Miller's "Whitman's Multitudinous Progeny: Particular and Puzzling Instances," in E. Folsom, ed., Walt Whitman: Centennial Essays (Iowa City: University of Iowa Press, 1994); Adrienne Rich, "Beginners," in Anne F. Herzog and Janet Kaufman, eds., How Shall We Tell Each Other of the Poet? (New York: St. Martin's Press, 1999), 6r-69.

11 During the I940s, Rukeyser corresponded with her publisher regarding her wish to edit a selection of Melville's writings. Although the book never went to print, Rukeyser's preparatory notes for the projected publication indicate that she read widely both primary and secondary material, including Parrington, Chase, Thorp, Olson, Matthiessen, Leyda and Mumford.

12 Muriel Rukeyser, “'The Usable Truth," Poetry: A Magazine of Verse, s 8 (July 194I), 206-9, 206. The article derived from a series of lectures that Rukeyser had given at Vassar College in I940, which were subsequently compiled and edited to produce the book The Life of Poetry in 1949 .

13 Stott discusses this in Documentary Expression and Thirties America (New York: Oxford University Press, I973), I 3 I.

14 Rukeyser, “The Usable Truth,” 206. 
anonymous. ${ }^{.15}$ As well as her rhetoric recalling that of Brooks and Frank in their use of natural imagery to recover the imaginative minds of dead representative Americans, Rukeyser's use of the words "fallen," "lives" and "anonymous" situates her call to arms within the immediate crisis of international conflict.

Throughout the article, Rukeyser develops the idea that poetry is usable "equipment," a vital part of American "heritage" and "tradition" which must engage in a relationship with the American public whereby each side "preserves" the life of the other. ${ }^{16}$ Written on the brink of America's entry into the Second World War, Rukeyser's article is a defence of poetry's use as a powerful energizer and weapon. Far from offering a method of escapism, Rukeyser promotes "the attitude of poetry" as a "fierce" and "vivid spirit" "with which we can face these battles," asserting that the "usable truth" of poetry lies in its "communication ... between human beings," which has always been an American "tradition."17 According to Rukeyser, "fear" of poetry corresponds to "the form and content of fear" characterizing the "machines of fright" which generate war, and whilst Rukeyser does not advocate war, she confronts its reality, offering an approach to human relations which draws on the lessons of an American ancestry, distilled in its poetry.

The American ancestor whose lessons Rukeyser chiefly draws upon in the article is Melville. Her language seems infused with patriotism and hope as she declares, "We can remember all our pride now, all our truth - in Melville's phrase, 'the usable truth.' We in America breathe the air of possibility." ${ }^{\prime 18}$ One year later, in the biography Willard Gibbs (1942), and eight years later in The Life of Poetry (1949), Rukeyser again referenced Melville's phrase, revealing that it originated from a letter of "courage" and "genius" from Melville to Nathaniel Hawthorne. ${ }^{19}$ She provides a lengthy quotation from the correspondence, in which Melville expounds upon the term "the usable truth" to mean "the apprehension of the absolute condition of present things as they strike the eye of the man who fears them not, though they do their worst to him." ${ }^{, 20}$

It is worth noting that Melville's phrase, "the usable truth," is probably a misquotation of "the visible truth." ${ }^{.21}$ The letter from which the term
15 Ibid.
16 Ibid., 206, 207.
17 Ibid., 207, 208.
18 Ibid., 208.

19 Muriel Rukeyser, Willard Gibbs: American Genius (New York: Doubleday, 1942), 354; idem, The Life of Poetry, 27, under the subheading "The Usable Truth."

20 Rukeyser, Gibbs, 354.

${ }^{21}$ Harrison Hayford, "Melville's Usable or Visible Truth," Modern Language Notes, 74, 8 (Dec. 1959), 702-5. 
originates was written in $185 \mathrm{I}$, and transcribed by Hawthorne's son Julian for publication in 1884 . Scholarship on the matter dating from the mid-r 940 os favours the interpretation "the visible truth," due to palaeographic examination, proof of Melville's bad spelling, and Julian Hawthorne's poor transcription techniques. ${ }^{22}$ Harrison Hayford, who first suggested the amendment in 1945, noted in 1959 that "no other phrase of Melville's was singled out more often in critical works of the r940s than 'the usable truth." "23 F. O. Matthiessen used it in 1941, and William Sedgewick in 1944; however, in Davis and Gilman's Letters, "the usable truth" was changed to "the visible truth," and all subsequent publications of the letters adhere to this amendment. ${ }^{24}$ Of course, Rukeyser's interpretation and application of the phrase does not alter in the light of the scholarly controversy that later surrounded it. Indeed, for Rukeyser, whose poetics were infused with the documentary aesthetic of visibility as testament to actuality, "the visible truth" served as a necessary component to usability and communication. By hoping to make the American public view poetry, and therefore each other, in a more open, connective way, Rukeyser wished to convey the message that "very closely, our lives are all implicated" in the making and preserving of poetry, and the creation of a usable past. ${ }^{25}$

Rukeyser's emphasis on poetry's use-value in her writing throughout the I940s reveals a pragmatic turn to her politics, and an engagement in a prevailing nationalism which documented and celebrated all areas of American experience. During her time at the Office of War Information (OWI) as visual information specialist (1942-43), Rukeyser wished to utilize the new documentary form of combined word and image to create posters in support of the American war effort. Speaking of the posters as poetry, Rukeyser believed that their usable and principle truth was the communication of ideas. She resigned from the OWI through anger at her superiors' apparent lack of regard for poetry, generated by their wish to create images which would "sell" the war. According to Rukeyser, such images were "emblems of pre-surrender," and a debasement of national attitudes and pride. Her resignation letter, also released to the national press, stated her conviction

22 Ibid., 703; the letter originally appeared in Julian Hawthorne, ed., Nathaniel Hawthorme and His Wife, Volume I (Boston, I 884), 387.

${ }^{23}$ Ibid., 702. Unpublished $\mathrm{PhD}$ thesis for Yale (1945).

24 Matthiessen, American Renaissance; Sedgewick, Herman Melville; The Letters of Herman Melville, ed. Merrell Davis and William Gilman (New Haven: Yale University Press, 1960), letter 83; republished under the name Herman Melville: Correspondence, ed. Lynn Horth (Evanston, IL: Northwestern University Press, 1993). $\quad 25$ Rukeyser, “The Usable Truth," 208. 
that "posters, like poems, are vivid and concise emblems of the spirit," and that during a time of war, "words and images are weapons."26

\section{"RYDER"}

In Melville, Rukeyser saw a vivification and coming together of words and images that offered modern America "lines of tradition, and emblems" with which to address the present. ${ }^{27}$ The critically neglected poem "Ryder" (A Turning Wind, 1939) is the earliest reference to Melville in Rukeyser's published works, and represents an important point of confluence between elements of a usable American tradition, documentary aesthetics and methods, and the poet's belief in the communicative influence of past lives. ${ }^{28}$ Albert Pinkham Ryder (1847-1917) was a visionary painter, whose subject was primarily the fierce, moonlit seascapes that characterized his New England home. Rukeyser's evocation of the painter draws on, among other texts, Paul Rosenfeld's Port of New York (1924), a collective work of cultural reclamation that was in turn heavily influenced by the "cultural-myth" rhetoric of Brooks, Frank and others. Appearing in the first biographical "Lives" series, "Ryder" is part of what constitutes in Rukeyser's work a similar project to construct a composite portrait of America.

Rukeyser borrowed significantly from Rosenfeld's essay on Ryder, at times lifting entire phrases, at others utilizing the motifs and ideas comprising Rosenfeld's critique. Citing that Ryder was a "New Englander, American, inheritor of pioneer blood," Rosenfeld argued that Ryder's paintings represented "the first deep expression of American life in the medium of paint."29 Likewise, Rukeyser labels Ryder a man "without tradition" who embodied the "irresponsible pioneer." Rosenfeld's writing a sensitivity to the poetry in Ryder's life and art that corresponded closely to her own understanding of the meaning and usevalue of poetry. Rosenfeld wrote of Ryder's canvases,

In us, too, in the moment of perception, the Ryders create a sum. The realm of feeling into which they initiate us brings to a close a long cycle of

26 A copy of the letter is in the Rukeyser Papers, Library of Congress, Washington, DC, Box II: 8, Folder 12.

27 Rukeyser, "The Usable Truth," 207.

${ }^{28}$ Louise Kertesz's book The Poetic Vision of Muriel Rukeyser (Baton Rouge and London: Louisiana State University Press, 1980) remains the only publication to examine the poem in any detail, awarding it two (160-62) pages of analysis.

29 Paul Rosenfeld, Port of New York (Urbana and London: University of Illinois Press, 1966; first published 1924), 10, 5.

${ }^{30}$ Muriel Rukeyser, "Ryder," in The Collected Poems of Muriel Rukeyser, ed. Janet E. Kaufman and Anne F. Herzog (Pittsburgh, PA: University of Pittsburgh Press, 2006), i 87 (hereafter abbreviated to $C P$ ). 
wandering ... there comes something full of what lies between us and American life ... to be an American and to have shared in the painful western adventure becomes a wonderful thing. ${ }^{31}$

Rosenfeld's belief that "in the moment of perception, the Ryders create a sum" of imagination and experience in those who witness them is echoed in Rukeyser's emphasis on the visuality of Ryder's life and work, and her repeated allusion to the "assemblages" of waters and distinctive currents of thought which punctuate his physical and psychological environment. The poem begins,

Call himself unbegun, for the sea made him; assemblages of waters gave him his color.

But not the sea; coast-line, coast-water, rising sfumato from smoke-holes of the sea, pitching onto the black rock of the ocean-edge. But not the coast-line; the Atlantic coast, flinging him headlong from its rigors into his art. ${ }^{32}$

The rhythmic swell of the sea, "rising ... pitching ... flinging," carries the reader to the place of Ryder's art: New Bedford, Massachusetts, a busy whaling town. By figuring Ryder as "the Atlantic coast," Rukeyser suggests Ryder as the starting point of American cultural tradition, and the eddying and swirling waters that gather at "the ocean-edge" serve as symbol of the movement of his thoughts and his experience.

Ryder's status at the start of the poem as "unbegun" is similar to the supposed state of America before the arrival of the first European settlers. Rukeyser's reader/witness approaches Ryder at the point of his conception by the poet as an American ancestor. Echoing Rosenfeld, Rukeyser imagines Ryder "drowning deep/among the mysteries of the painful western adventure"; his passage to the New World an experience close to death, as he arrives at the coast "drowning" and "circling/in unappeased circles." The repetition of "tempests," "lightning" and "whirlpools" throughout the poem helps to construct a pervading theme of the cruelty of untameable nature; however, Rukeyser sets the "terrible foreboding" aspect of Ryder's canvases in opposition to the themes of life and birth that she also recognizes within his works. The perpetual presence of the sea in the poem constitutes both a threat to human safety and a reminder of the first passage to the New World; a symbol of beginning that Ryder, Rukeyser and Melville utilize in their work. Hence Ryder both embraces the destruction that the ocean's contact with the land and its dwellers might bring, and holds the

31 Rosenfeld, I6-I 7 .

32 CP, i 85. 
"mind" of America within his own poetic and artistic sensibility, "to paint the tragic landscape that breeds us here,/the deep life ... whose soil/is in our mind, the imagination of this geography."

Rukeyser connects Ryder with America both geographically and genealogically, at the same moment connecting the soil of America with the collective imagination of its people. Additionally, by referencing the ocean throughout the poem, Rukeyser arguably develops Brooks's initial image of America as a "vast Sargasso Sea" in which a "welter of life" was "drifting" without direction. Painting both "the tragic landscape" and the ocean, Ryder was able to translate visual experience into art; his canvases are for Rukeyser "emblems" of usable truth: "Ryder, emblematist,/divorced from the arts, believing in art alone,/master of meaning."

Circular symbols and spirals as images of renewal and growth feature prominently in "Ryder," present in the mixing "waters" by the shoreline; the "thunder revolving" in Ryder's mind; "the moon stark in the sky as a centre of whirlpool;" and "his head that was moon the centre of the storm." ${ }^{35}$ The cyclical patterns of death and renewal are also present in Rukeyser's evocation of one of Ryder's most famous pieces, "Death on a Pale Horse," in the lines, "Ryder, whose racecourse with its big horse Death/runs round the brain." "36 As Ryder moves away from what Rukeyser terms "formal painting" to "mystic reconciliations" (recalling Frank's assertion that "America is a mystic word"), he feels "the world enlarge/and never complete itself." 37 The form and motion of Ryder's world - a world all Americans have inherited - is spiral; it expands as it comes full circle, allowing a new perspective on what has gone before.

For Rukeyser's Ryder, "the usable truth" begins in a "moment of perception," or, as Rukeyser later termed it, "a moment of proof," that leads to the dual working of imagination and memory. Under the heading "The Usable Truth" in The Life of Poetry, Rukeyser asserts that "art and nature are imitations, not of each other, but of the same third thing - both images of the real, the spectral and vivid reality that employs all means." When this twofold reality is spoken through poetry, a repressed need for both the tradition and the "immediacy" of meaning is addressed, for "we wish to be told, in the most memorable way, what we have been meaning all along." 38

\footnotetext{
${ }^{33}$ Ibid. ${ }^{34}$ Ibid., $187 . \quad 35$ Ibid., I $85-87$.

36 Death on a Pale Horse or The Race Track (1895-1910), Cleveland Museum of Art; CP, 186.

${ }^{37} C P, \mathrm{i} 86$.

38 Rukeyser, The Life of Poetry, 26.
} 
This "moment of proof," in which the reader becomes a responsible "witness," 39 begins with visual awareness, as in "Ryder":

He believes with his eye, he lives in the foreboding empty tempests of the mind, thunder revolving among his blackest noons; remembers voyages to fabulous harbours whose event was sea. ${ }^{40}$

Rukeyser again seems to rely heavily on Rosenfeld here, who had stressed Ryder's capacity to retain a seen image and "work from the image in the brain," rather than physically in front of it. ${ }^{\mathbf{4 1}}$ However, Rukeyser's choice of the word "believes" allows Ryder an understanding of truth that correlates with her idea of poetic communication. By re-visioning Ryder's own visuality, Rukeyser identifies the man and his art as both usable and visible truth. Ryder is thus located in the past and the present simultaneously, and the poem becomes an injunction to follow Ryder's example of believing by looking, rather than of looking to believe. This utilization of visible truth retained in the memory aligns Ryder with Melville for Rukeyser. Importantly, Rukeyser's unpublished notes suggest that she intended "Melville to be illustrated by Ryder" in the poem. ${ }^{\mathbf{2}}$

It is remarkable that, despite Melville featuring prominently in "Ryder," no critical attention has been paid to the fact. Allusion to Melville arguably occurs in the first line, "Call himself unbegun." The line recalls the famous opening injunction of Moby-Dick: "Call me Ishmael." Rukeyser's early depiction of Ryder as a man "made" by, and involuntarily drawn to, the sea recalls Ishmael's initial confession to experiencing a desperate need to go to sea whenever he is oppressed by the "civilized" strictures of American life. By beginning her poem in such a way, Rukeyser establishes Ryder as a man shaped by the sea and by the life of a fellow American; it is thus Melville who is established before Ryder as an American ancestor.

At the outset of Moby-Dick, the character of Ishmael introduces a dialectic of truth and possibility, which relies partly on the giving and assuming of names and purpose. ${ }^{43}$ By poetically re-visioning Ishmael's injunction, Rukeyser transfigures "me" into "himself" and "Ishmael" into "unbegun,"

39 Rukeyser preferred the term "witness" over "reader," "listener," or "audience." Ibid., 175. $\quad 40 C P$, i 86.

42 The MR Papers, Box I: 30 , Folder 3.

43 More recent criticism on the subject of identity in Moby-Dick after that of the "myth and symbol" school may be found in Eric Mottram's "Grown in America: Moby-Dick and Melville's Sense of Control," in A. Robert Lee, ed., Herman Melville: Reassessments (London and Totowa, NJ: Barnes and Noble, 1984), 90-I I 5 ; and Samuel Kimball's "Uncanny Narration in Moby-Dick," American Literature, 59, 4 (Dec. 1987), 528-47. 
thus immediately opening several dialogues between Melville, Ryder, their works and their "witnesses" (I use Rukeyser's terminology). Persons are both fused and confused; Rukeyser allows the reader/witness identification with Ryder at the same time as she allows Ryder identification with the sea, yet in the next line she withdraws from her position of certainty: "But not the sea; coast-line, coast-water." In lines that surge forward and retreat like ocean waves, Rukeyser reimagines Ryder as a symbolic figure of American heritage; the product of a coming together of opposites, the American land and the specifically "Atlantic" sea that breaks against it. ${ }^{44}$

Rukeyser describes New Bedford, where Melville also lived a large portion of his life, as a meeting-place of the opposites of good and evil, "Whose whaling port acknowledges the fearful content of evil and the swift-lit blessed light, Melville's 'latent horror of life' in the whale water that Ryder, whose racecourse with its big horse Death runs round the brain, knew." ${ }^{\text {"45 }} \mathrm{By}$ linking the swirl of ocean water in the "whaling port" with the unending galloping of the figure of Death on a circular racecourse, Rukeyser compounds the art and biographies of Melville and Ryder, with obvious references to Moby-Dick and Ryder's well-known painting. The phrase "the latent horror of life" is a misquotation from chapter 38 of Moby-Dick, in which life's "latent horror" becomes obvious to Starbuck as he stands in reverie on the deck at dusk, and at last understands through solitary contemplation the duality of the sea in terms of the illusory calm of its appearance on the surface, and the violence that lurks beneath ("Oh life! 'tis now that I feel the latent horror in thee!"). ${ }^{46}$ By imagining Ryder as physically and mystically part of the land and of the seascapes he paints, Rukeyser in turn paints him as a type of Ishmael/Melville; both an observer of and participant in American experience.

Melville is alluded to at other points within "Ryder." Recalling the dramatic contrast of Ryder's storm paintings, Rukeyser describes the violence of Ryder's method and effect:

And at the last slashed poker through the cloth, a knife of lightning, white as space, leaping white! out of darkness!

Out black night leaping, rider to flame. ${ }^{47}$

The source is chapter ing of Moby-Dick, "The Candles," in which the Pequod encounters a tempest, and Ahab refuses to listen to the advice of Starbuck to turn the ship back to safety, out of the storm and away from the

${ }^{44} C P, 185$.

${ }^{46}$ Herman Melville, Moby-Dick or The Whale (New York: Penguin, I992; first published i 8 5 I), chapter 38: "Dusk," I85.

$47 C P, \mathrm{i} 86$. 
whale. Rukeyser links Melville's and Ryder's art through allusion to the shared material of canvas, or "cloth," which comprises both the surface for Ryder's paintings and the sails of the Pequod. Ryder slashes his canvas to create "a knife of lightning" similar to that which tears the canvas sail of the Pequod in "The Candles," opening the sky to a flash "as white as space." However, it is with the character of Ahab, rather than Ishmael, that Rukeyser now identifies Ryder. Ahab's Shakespearean soliloquy in the candlelight of the deck, amid "sudden, repeated flashes of lightning," is an oath of opposition and resilience:

The lightning flashes through my skull ... Light though thou be, thou leapest out of darkness; but I am darkness leaping out of light, leaping out of thee! ... There burn the flames! Oh, thou magnanimous! Now I do glory in my genealogy ... Leap! Leap up, and lick the sky! I leap with thee; I burn with thee; would fain be welded with thee .... ${ }^{48}$

Identified with Ahab, Ryder is further established by Rukeyser as a man in whom contraries meet and unite; a man created by the natural forces surrounding him. As Ahab glories in his descent from fire and lightning, Ryder, Rukeyser reminds us, was "made" by the sea. However, Ryder is also created by the "black night"; his person fused with images of life and death, as the obvious homophony of "rider"/Ryder recalls the spectre of death on a racehorse. Again, Rukeyser highlights the cyclical pattern of death and rebirth, and the identification that she establishes in the poem between Ryder, Melville, Melville's characters and the reader creates a passage which may lead to a clearer understanding of the world and one's place in it. By refiguring Ryder in connection with Melville, Rukeyser forges a meeting between American ancestors, as well as between her reader/witness and the lives she portrays. A usable truth is generated from this personal encounter. In The Life of Poetry, Rukeyser maintains that "if darkness leaps from light; even so, there is redemption, and it lies in the sympathy with another human being." "49

"Ryder" also represents a meeting place of documentary and narrative, or the epic and the lyrical. Between stanzas of psychological lyricism in which Melville is referred to twice, Rukeyser inserts an inventory of the contents of Ryder's room:

wreckage of boxes, propped-leg, easel, couch, ashes, coal-keg, shells, bronzed tarnished coffee-pot, books, paints, piled broken furniture, varnish drippings, matches, cans, newspapers stacked up, plaster falling with a scurrying like mice, paper bannering from the walls, the stains, the path cleared to the stuffed chair crammed with poems, money, checks, poems, the bathtub filled with clothes $-{ }^{50}$

${ }^{48}$ Melville, Moby-Dick, 55 I.

49 Rukeyser, The Life of Poetry, 73.

${ }^{50} C P, \mathrm{I} 86$. 
The inclusion of this passage in the poem has a similar effect to that created by the inventories and utilitarian descriptions in Moby-Dick, as well as calling to mind Whitman's cataloguing of the visual proofs of American experience in Leaves of Grass. By exploring the physical dimensions of Ryder's intimate environment, Rukeyser opens another perspective on his life and work, which again extends to include the life of Melville, and both Ryder's and Melville's comprehension of the objects of reality. In 1956, the American studies critic John Ward wrote of Melville's ability to extend the metaphysical meaning of an object so that "there can be no end to the amount of and the kinds of relationships established." ${ }^{51}$ Claiming that much of Melville's writing had the style of a "documentary report," Ward proposed that the seemingly "digressive passages" had a "thematic significance." He argued that by trying to understand physical reality, Melville was attempting "to arrive at an understanding of spiritual reality." 52 Chapters involving inventories, detailed descriptions of procedures, tools, and analyses of the whale were set against "the spiritual and cosmic points of view of the main characters and of the novel itself." The effect, according to Ward, was of "the illusion of objectivity," or "a wide view of life" - an effect that Rukeyser seemed to be seeking in The Book of the Dead (1938) when she urged her readers to "widen the lens and see."

In "Ryder," the relevance of Rukeyser's list of objects enlarges the poem in terms of relation and meaning. Rukeyser stacks object upon object, layering them in a manner that evokes both the crowded confines of Ryder's room and the methods of his art. In the next stanza, Ryder stands in his cluttered studio, "layering the paint on/stacking color on" as he builds an image ${ }^{54}$ Several items listed reappear later in the poem; the "ashes" are mixed with the "paints" and spread into the "blackness" on the canvas that in turn recalls the Pequod's torn sails; the "shells" summon up fragments of "coast-line"; the "path cleared" to the "poems" is forged also by Rukeyser's own poem to a usable, ancestral life. ${ }^{55}$ This merging of the documentary and the lyrical in "Ryder" is an example of Rukeyser's appreciation for what she recognized as a "poetry of meeting-places."

51 John Ward, "The Function of the Cetological Chapters in Moby-Dick," American Literature, 28, 2 (May 1956), 164-83, 173. $\quad{ }^{52}$ Ibid., 165, 167. $\quad{ }^{53}$ Ibid., 170; CP, I 10.

${ }^{54} C P, \mathrm{i} 86$.

55 Frederic Newlin Price, a writer and friend of Ryder, actually lists "eggshells" among the contents of his room in Ryder [1847-19I7]: A Study of Appreciation (New York: William Edwin Rudge, 1932), xiii. Rukeyser utilized Price's biography of Ryder in her own account of the painter and his work.

56 Rukeyser, The Life of Poetry, 20. 
she expands upon the idea, arguably instigated by her readings of Melville, as central to her own poetics.

\section{THE MEETING OF OPPOSITES}

Rukeyser believed poetry to be the expression of connection and communication, seeing it as a meeting-place in which "form and content, relation and function, reach and merge." edged Rukeyser's insistence upon the necessity of unhindered relations between all things, there seems to be no critical appreciation of her application of this theory in terms of formal method, nor is there any critical discussion of the influential role Melville played in its formation.

In the chapter of Gibbs entitled "Three Masters: Melville, Whitman, Gibbs," Rukeyser figures the three contemporaries as American pioneers, each in the tradition of axiom-breaking, and each representing a different, yet connected, line of American ancestry. Evoking her earlier untitled "Lives" poem, Rukeyser asserts that the three men "are the ancestors, they walk silent in our streets ... they speak to us." Similar to Matthiessen, Rukeyser offers a reading of the Pequod as a "symbol for the conflicting energies of existence." Noting that "the two energies of the captain and the whale are not single, but clusters of forces working against each other," Rukeyser links the physician Gibbs's theory of the phases of matter with Melville's exposition of the whale chase in Moby-Dick: just as Gibbs proved that truth was an accord that occurred in process, Melville unrolled "the image of a system," demonstrating that "[w] hatever triumph there is, does not arrive at the end, but moment by moment during the chase." Ostensible opposites work in a relation of conflict that leads to equilibrium but never to finality, and Rukeyser posits that the "logic" of their "balance" "lies in analogy." Observing that "Melville knew, as well as any scientist, how far language falls short of these recognizable truths," Rukeyser quotes Melville's recognition of the connectedness between apparent contraries: "O Nature, and O Soul of man! ... how far beyond all utterance are your linked analogies."

By highlighting fundamental and universal connections between physics and poetry, the scientific and the subjective, Rukeyser also draws connections between the past and the present, represented by Gibbs, Whitman and Melville, and their continuing legacies to the American mind. According to Rukeyser, Melville saw more than most the "truth" of the human imagination, asking only that it be "usable ... that it fit into a tradition, make itself 
at once plain to many." Melville also represented "democracy, whose equilibrium depends to a great extent on the inclusion of opposites. " communicable truth within himself and within others, and to figure it as cultural artefact, aligned him with Gibbs and Whitman in their shared ability to "create the creative."

In The Life of Poetry Rukeyser provides a proper exposition of her poetics of meeting-places, supported by a close reading of Melville's poetry from Battle Pieces. Stating that Melville's prose "announces the problem of evil" in terms of its "conflict" with innocence, Rukeyser asserts that "in the poems," for the first time in American literary history, "the oppositions turn to music." She relies on Melville's poetry to speak for both the cultural state of America and her own relational poetics, quoting from a draft of Melville's poem "Art": "In him who would evoke-create,/Contraries must meet and mate." ${ }^{\text {22 }}$ Understanding that "the Civil War turned him into a poet who saw aspects of wars to come," Rukeyser relates Melville's experience of war to that of the present generation's, noting the inseparability of art, war and American cultural history; "simply, the line of culture was begun in America at a point of open conflict." ${ }^{\text {"63 }}$ Recognizing war to be central to an American idea of cultural heritage, Rukeyser considers Melville's ability to "create" from conflict inherently and edifyingly American, stating, "this country was begun in axiom-breaking. ",64

Rukeyser also sees conflict within the self as an important catalyst to the expression and recording of a particularly American experience. Again, she attempts to strengthen attitudes to war or crisis via the utilization of poetic documents, connecting Melville's poem of sexuality and self-appraisal, "After the Pleasure Party" (1891), with contemporary approaches to personal and social realities. Rukeyser believed that there are "two kinds of poems," those of "unverifiable facts, based in dreams, in sex ... and the other kind being the document, the poem that rests on material evidence." We might view Melville's poem as "unverifiable fact," and Rukeyser's appreciation of it as an example of her wish to join it to the documentable fact of war. ${ }^{65}$ The selfhood of Melville's poet-narrator, established only through

\footnotetext{
59 Ibid., 355.

62 Rukeyser, The Life of Poetry, 67.

60 Ibid., 356-57.

65 Muriel Rukeyser, "The Education of a Poet" (an essay adopted from a talk given by Rukeyser under the auspices of the Academy of American Poets in December 1976), published in The Writer on Her Work, ed. Janet Sternberg (New York: W. W. Norton and Co., 2000), 217-30, 226. I expand upon his idea in my unpublished $\mathrm{PhD}$ thesis (King's College London, 2008).
} 
coupling with a "co-relative" in the poem, is figured as "the human integral clove asunder":

Why hast thou made us but in halves -

Co-relatives?...

If these co-relatives never meet

Selfhood itself seems incomplete. ${ }^{66}$

Via this poem, Rukeyser understands Melville as "a battleground of forces"; she sees his internal conflict "penetrate" his work, and by so doing, infiltrate the mind of "America." 67 Rukeyser posits that such examples of inner conflict and self-discovery constitute "the discovery of America." ${ }^{\prime 68}$ The idea that tradition is not given to the people easily is reiterated in Rukeyser's I 944 article "Under Forty," in which she connects the idea of freedom with the ability "to choose one's ancestors, to go with their wishes and their fight." By heeding the lessons of their ancestors, Americans might follow them in the confrontation of present conflicts.

Anne Herzog has suggested that Melville's artistic fusion of opposites appealed to Rukeyser's sense of the necessity of integration, and Cooper has argued that Rukeyser's connective thinking stems primarily from her affinity with Whitman, quoting a passage from The Life of Poetry in which Rukeyser, similar to Matthiessen, writes of Whitman's rhythms, measured against “an ideal of water at the shore, not beginning nor ending, but endlessly drawing in, making forever its forms of massing and falling among the breakers, seething in the white recessions of its surf, never finishing, always making a meeting-place." ${ }^{\text {"70 }}$ However, I would argue that Melville's ability to fuse "contraries" in the meeting-place of art did not support Rukeyser's poetic principles so much as inspire them. Ten years before The Life of Poetry was published, Rukeyser had employed precisely the same imagery to evoke Ryder, through whose life, we remember, she intended "Melville to be illustrated" and read. Additionally, there is no evidence to suggest that Rukeyser employed the term "meeting-place" to refer to her art before the start of her involvement with Melville's work in the late I930s.

\section{CONCLUSION: “AFTER MELVILLE”}

The hiatus between the poem "After Melville" (Breaking Open, 1973) and Rukeyser's earlier use of Melville as poetic subject, coupled with the elegiac

\footnotetext{
${ }^{66}$ Rukeyser, The Life of Poetry, $7 \mathbf{1}-72$.

67 Ibid., 74, 70-7I.

68 Ibid., 75 .

69 Muriel Rukeyser, "Under Forty," in Contemporary Jewish Record, VII (Feb. I944), 4-9, 8.

70 Anne F. Herzog, "“Anything Away from Anything': Muriel Rukeyser's Relational Poetics," in Anne F. Herzog and Janet Kaufman, eds., How Shall We Tell Each Other of the Poet (New York, 1999), 32-44, 42. Cooper, 'Meeting-Places', xxv, quoting The Life of Poetry, 78.
} 
connotations of the poem's title, seems to indicate both a return to previous poetic influences and a query into new points of cultural reference, after the surge of interest in Melville had subsided.

Again, the sea and the "sea-coast" establish a theme of recurrence and creation throughout the poem, and are images that remain inseparable from the figure of Melville. He is figured as both "the shore of the sea" and "the sea we carry to our star," representing not only a durable symbol of a "usable past," but also the very substance of the origin of creation. ${ }^{71}$ In the three sections of the poem, Rukeyser pictures three stages in the development of Melville's legacy, via exchanges of looking. First "the sea-coast looks at the sea," and we understand the "shore" to be Melville, swept by "configurations of water" to "the deep land" of America. ${ }^{72}$ As the poem progresses, Melville and his contemporaries Whitman, Hawthorne and Dickinson "come into our lives," as the sea is figured as modern American experience; by "diving the sea deeper" than any other, Melville "swims our world," thereby "revealing us, who are his afterlife." In the final section, Melville's gifts to America are manifested in the lives of those who, by looking at the world and each other, enter a dialogue of reciprocal awareness. By teaching subsequent generations how to receive the reality of lived experience, Melville has created the creative, and his legacy will therefore live "forever."73

Through recourse to a Melvillean meeting of opposites, and a continuing engagement with the documentary dynamic of looking and being looked at, Rukeyser weaves together the strands of her lifetime's thought in her mature work. The poem blends anonymous objectivity with a more personal lyricism to create what I would term a subjectively epic tale of America. "Against the corroded wars and sources of wars, a lake of being born .../One man giving us forever the grapes of the sea." is born, inseparable from that of America. Melville represents renewal, "the reborn wave," recalling Rukeyser's initial "Lives" poem in which she imagines the dead "charging our latest moment with their wave." 75 That Melville "drowns/for the sake of our look into each other's body and life" suggests an almost messianic, Christ-like quality to him, echoes of which may be found in the poem's titular reference to (American) existence "after" his death. After the "Melville revival," and in "After Melville," Rukeyser was not, therefore, advocating a moving away from Melville to choose a new ancestor-teacher, but demonstrating America's continuing need to follow his example.

${ }_{73}$ Rukeyser, "After Melville," CP, 500-1, 500.

73 Ibid., 501.

${ }^{74}$ Ibid.

72 Ibid., 500.
75 Ibid., I 82. 